\title{
Dynamic Economic Dispatch dengan Mempertimbangkan Valve Point Effect dan Multiple Fuel Options Menggunakan Metoda Ant Colony Optimization
}

\author{
Mochamad Luthfiyansah, Rony Seto Wibowo, Adi Soeprijanto \\ Departemen Teknik Elektro, Fakultas Teknologi Elektro, Institut Teknologi Sepuluh Nopember (ITS) \\ e-mail: luthfiyansah@gmail.com, ronyseto@ee.its.ac.id, adisup@ee.its.ac.id
}

\begin{abstract}
Abstrak-Biaya pembangkitan yang ekonomis pada pembangkit thermal sulit untuk ditentukan karena banyak faktor yang perlu di pertimbangkan. Economic dispatch adalah solusi untuk mendapatkan biaya pembangkitan yang ekonomis dan efisien yaitu dengan perhitungan optimisasi biaya. Economic dispatch hanya digunakan untuk satu level beban. Dynamic Economic Dispatch (DED) merupakan solusi untuk menentukan pembagian pembebanan dari setiap unit pembangkit secara ekonomis dalam rentang waktu 24 jam. Beberapa faktor yang perlu dipertimbangkan dalam perhitungan DED yaitu valve point effect (VPE) merupakan efek dari pembukaan katub bahan bakar pada unit pembangkit thermal dan multiple fuel options (MFO). parameter tersebut menjadikan kurva biaya pembangkitan menjadi non-convex. Dengan menggunakan metode optimisasi didapatkan biaya seminimal mungkin serta tetap melayani kebutuhan daya ke konsumen selama 24 jam. Pada studi ini metode optimisasi yang digunakan yaitu Ant Colony Optimization. Fungsi objektif yang dioptimisasi adalah biaya pembangkitan minimal dengan pertimbangan VPE dan MFO. Hasil pengujian simulasi yang didapatkan pada sistem 5 Unit pembangkit dan 10 Unit pembangkit yaitu pengaruh dari pertimbangan VPE dan MFO pada fungsi objektif yang disediakan. Sehingga menghasilakan perubahan biaya pembangkitan yang signifikan untuk memenuhi kebutuhan konsumen selama 24 jam.
\end{abstract}

Kata Kunci-Dynamic Economic Dispatch, valve point effect (VPE), multiple fuel options (MFO), Ant Colony Optimization (ACO).

\section{PENDAHULUAN}

$\mathrm{P}$ ERAN pembangkit untuk mensuplai permintaan daya listrik yang terus bertambah diupayakan mampu bekerja secara maksimal dan efisien dengan biaya pembangkitan yang minimum untuk memenuhi permintaan beban. Hal ini menyebabkan kendala pada sisi pembangkit ditambah fluktuasi kebutuhan daya disisi beban dalam satu periode [1]. Sehingga perlu dilakukan pengoptimalan generator scheduling dalam membangkitkan daya dengan harga minimum. Permasalahan yang muncul yaitu, bagaimana cara menentukan koordinasi antar pembangkit dalam upaya melakukan optimal generator scheduling untuk memperoleh biaya pembangkitan minimum dengan mempertimbangkan beberapa parameter agar perhitungan dari daya yang dibangkitkan mendapatkan perhitungan optimisasi dengan ketepatan sebaik mungkin. Salah satu cara untukmengatasi permaasalahan ini yaitu dengan dilakukannya perhitungan
Dynamic Economic Dispatch, (DED) pada sistem tenaga listrik [2].

Fungsi utama DED sebagai perhitungan untuk membangkitkan daya dari setiap pembangkit yang beroperasi untuk dapat memenuhi kebutuhan beban pada biaya pembangkitan paling minimal secara real time dengan memperhitungkan batasan ramp rate. Ramp rate Parameter ramp rate menyebabkan pembagian pembebanan pada satu waktu tertentu akan mempengaruhi pembagian pembebanan pada waktu lain [2].

Pada sistem pembangkit yang sebenarnya banyak parameter yang perlu diperhatikan dalam perhitungan DED. Parameter lain yang akan dipertimbangkan adalah efek dari katup bahan bakar untuk memutar turbin serta beberapa pilihan bahan bakar yang optimal. Valve point effect (VPE) yaitu timbulnya ripple pada kurva unit pembangkit yang dihasilkan dari wire drawing effect yang terjadi karena masing-masing katup uap dalam turbin mulai membuka [3]. Untuk mempertimbangkan kurva biaya yang akurat dari setiap unit pembangkit, efek katup-titik (VPE) harus dimasukkan dalam model fungsi biaya. Oleh karena itu, fungsi sinusoidal dimasukkan ke dalam fungsi kuadrat.

Unit pembangkit dengan beberapa pilihan bakan bakar menghasilkan kurva biaya yang non-convex. Fungsi biaya yang dihasilkan disebut "fungsi biaya hybrid." Setiap segmen dari fungsi biaya hybrid terdiri dari beberapa informasi tentang bahan bakar yang digunakan atau operasi dari tiap-tiap unit [4]. Karena unit pembangkit yang disediakan pertimbangan multiple fuel options (MFO), masing-masing unit harus diwakili dengan beberapa fungsi kuadrat piecewise untuk mencerminkan efek dari perubahan jenis bahan bakar [5].

Permasalahan yang akan dibahas dalam studi ini adalah penyelesaian permasalahan DED untuk mendapatkan pembangkitan yang optimal dengan harga yang minimum pada setiap unit pembangkit yang tersedia. Metode penyelesaian yang digunakan yaitu algoritma ACO yang dilakukan dengan MATLAB. Batasan masalah yang difokuskan pada tugas akhit ini yaitu perhitungan DED dengan parameter VPE dan MFO yang kemudian dilakukan perbandingan tanpa memperhatikan parameter VPE dan MFO. Data beban tidak noleh melebihi kemampuan pembangkitan total pembangkit dan semua pembangkit diasumsikan dalam keadaan menyala. 


\section{TEORI PENUNJANG}

\section{A. Economic Dispatch}

Economic Dispatch (ED) merupakan permasalahan ekonomis utama dalam operasi sistem tenaga listrik. Pembagian pembebanan pada pembangkit yang ada dalam sistem secara optimal dan ekonomi, dengan menentukan besarnya daya yang dibangkitkan dari masing-masing generator dengan batasan-batasan teknis dan oprasional merupakan tujuan dari economic dispatch [5]

$$
F_{i}\left(P_{i}\right)=a_{i} P_{i}^{2}+b_{i} P_{i}+c_{i}
$$

Batasan dalam permasalahn ED dibagi menjadi dua yaitu equality constraint dan inequality constraint.

\section{B. Dynamic Economic Dispatch}

DED adalah pembagian daya yang harus dibangkitkan oleh generator dalam suatu sistem tenaga listrik secara realtime dalam rentang waktu yang ditntukan ( 24 jam) sehingga dapat memenuhi kebutuhan beban dengan biaya minimum [2].

\section{1) Fungsi Objektif}

Fungsi objektif dari permasalahan DED merupakan perulangan dari fungsi objektif ED dalam rentang waktu [6].

$$
F_{i}^{t}\left(P_{i}^{t}\right)=a_{i} P_{i}^{2^{t}}+b_{i} P_{i}^{t}+c_{i}
$$

Pada kenyataannya unit pembangkit dengan katup turbin uap menunjukkan variasi fungsi biaya bahan bakar yang beragam. Sehingga kurva karakteristik dari output pembangkit tidak sehalus seperti yang dirumuskan pada persamaan (2). Efek dari katup turbin uap menyebabkan ripple pada kurva pembangkitan [3].

$$
F_{i}\left(P_{i}^{t}\right)=a_{i}+b_{i} P_{i}^{t}+c_{i} P_{i}^{2, t}+\mid e_{i} \times \sin \left(f_{i} \times\left(P_{\text {min, } i}^{t}-P_{i}^{t}\right) \mid\right.
$$

Unit pembangkit dengan beberapa pilihan bakan bakar menghasilkan kurva biaya yang non-convex [1]. Tujuan utama DED dengan opsi beberapa pilihan bahan bakar adalah untuk menemukan bahan bakar mana yang paling ekonomis untuk digunakan. Fungsi kuadrat piecewise digunakan untuk mewakili beberapa pilihan bahan bakar dan fungsi biaya seperti yang ditunjukkan pada Gambar 2 [5]. Fungsi biaya hybrid dengan batasan ketidaksetaraan direpresentasikan pada persamaan (4) [7].

$$
F_{i}\left(P_{i}^{t}\right)=\left\{\begin{array}{c}
a_{i 1}+b_{i 1} P_{i}^{t}+c_{i 1} P_{i}^{2, t},(\text { fuel } 1) P_{\text {min }, i}^{t} \leq P_{i}^{t} \leq P_{1 i}^{t} \\
a_{i 2}+b_{i 2} P_{i}^{t}+c_{i 2} P_{i}^{2, t},(\text { fuel } 2) P_{1 i}^{t} \leq P_{i}^{t} \leq P_{2 i}^{t} \\
\ldots \ldots \ldots \\
\ldots \ldots \ldots \\
\ldots \ldots \ldots \\
a_{i k}+b_{i k} P_{i}^{t}+c_{i k} P_{i}^{2, t},(\text { fuel } k) P_{(i k-1)}^{t} \leq P_{i}^{t} \leq P_{\text {max }, i}^{t}
\end{array}\right.
$$

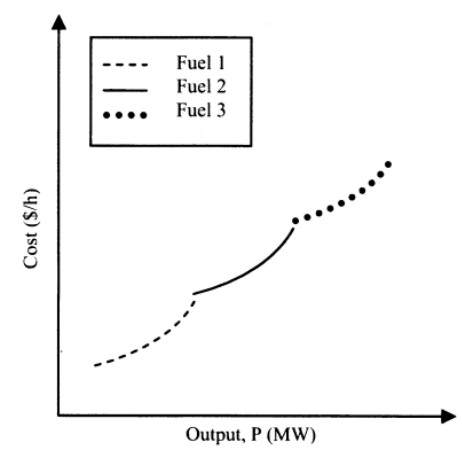

Gambar 2. Kurva Biaya dengan Suplay 3 Type Bahan Bakar.

\section{2) Kesetimbangan Daya}

Operasi sistem tenaga listrik pada frekuensi konstan dapat disebut juga power balance, yaitu pembangkitan daya real sama dengan total beban yang diminta. Sehingga kombinasi daya output yang dibangkitkan oleh tiap-tiap generator pada sistem dapat memenuhi kebutuhan daya dari sistem tenaga listrik (equality constraint) [2], yang dituliskan sebagai persaman (5).

$$
\sum_{i=1}^{N} P_{i}=P_{D}
$$

\section{3) Batasan Operasi}

Batasan yang perlu diperhatikan selanjutnya yaitu daya yang dibangkitkan generator harus memenuhi batas minimal dan maksimal dari unit-unit generator itu sendiri (inequality constraint) [7], yang dituliskan pada persamaan (6).

$$
P_{i} \min \leq P_{i} \leq P_{i} \max
$$

\section{4) Konstrain ramp rate}

Pada batasan ramp-rate juga terdapat laju nilai naik (UR) dan laju nilai turun (DR). Batasan ramp-rate digunakan untuk mencegah efek yang tidak diinginkan akibat dinamika perubahan yang cepat dan melebihi kemampuan generator, baik dalam pembebanan maupun pelepasan daya [6]. Batasan oprasi dengan ramp-rate ditunjukkan pada persamaan (7).

$$
\begin{gathered}
U R_{i} \geq P_{i}^{t}-P_{i}^{t-1} \\
D R_{i} \geq P_{i}^{t-1}-P_{i}^{t}
\end{gathered}
$$

\section{5) Ant Colony Optimization}

ACO adalah algoritma meta-heuristik evolusioner berdasarkan representasi grafik. Ide utama ACO adalah memodelkan masalah sebagai pencarian jalur biaya minimum dalam sebuah grafik. Semut buatan berjalan melalui grafik ini dan mencari jalan yang bagus. Jalan yang lebih baik ditemukan sebagai hasil yang muncul dari kerja sama global antar semut di koloni tersebut.

Pada awalnya semut mencari lintasan secara acak. Ketika semut menemukan sumber makanan, semut akan berjalan kembali ke sarangnya dengan meninggalkan jejak berupa feromon yang menunjukan jalan menuju sumber makan tersebut [6]. Hal ini dapat digambarkan pada Gambar 3a. Semut berada pada garis lurus yang menghubungkan sumber makanan dengan sarangnya. Pada Gambar 3b, semut itu berada tepat di depan rintangan dan mereka tidak bisa terus melangkah. Karena itu, mereka harus memilih antara belok kanan atau kiri. Setengah semut memilih berbelok ke kanan dan separuh lainnya memilih berbelok ke kiri. Situasi serupa muncul di sisi lain hambatan pada Gambar 3c. Semut memilih jalur yang lebih pendek Karena lebih cepat menyusun kembali 
jalur feromon yang terganggu dibandingkan dengan yang memilih jalur yang lebih panjang. Dengan demikian, jalur yang lebih pendek menerima jumlah feromon lebih banyak per satuan waktu dan, sebagian besar semut memilih jalur yang lebih pendek. Karena umpan balik positif ini, semua semut dengan cepat memilih jalur yang lebih pendek pada Gambar 3d [7]. Hal ini mulai berhenti ketika ada semut yang menemukan sumber makanan yang lain.

Setiap semut akan membangun solusi berdasarkan state transition rule. Ketika membangun suatu solusi, setiap semut akan mengubah besarnya pheromone pada cabang yang dilaluinya berdasarkan local updating rule. Apabila semua semut telah selesai membangun solusi, jumlah feromon pada setiap cabang akan mengalami perubahan sesuai dengan global updating rule [6].

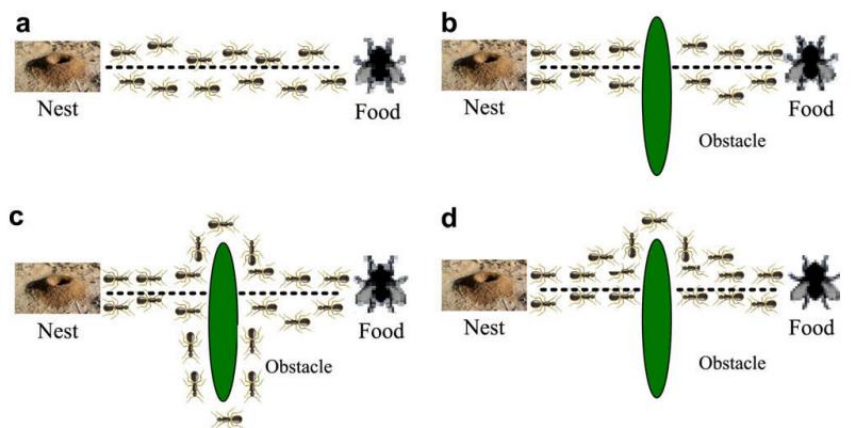

Gambar 3. Perilaku semut: (a) Semut mengikuti jalur menuju sumber makanan. (b) Hambatan muncul semut memilih apakah akan berbelok ke kiri atau kanan dengan probabilitas yang sama. (c) Feromon ditinggalkan lebih banyak pada jalur yang lebih pendek. (d) Semua semut telah memilih jalan yang lebih pendek.

\section{6) Grarf $A C O$}

Secara garis besar metode Ant Colony permasalahan terlebih dahulu dijabarkan dalam bentuk graft/jaringan. Dalam graft tersebut didefinisikan $(N E)$ yang merupakan himpunan simpul dan percabangan yang nantinya menjadi jalur semut untuk menuju sumber makanan [6].

\section{7) State Transition Rule}

Pemilihan simpul yang digunakan dalam metode ACO dirumuskam sebagai persamaan (8) dan (9).

$$
P_{i}^{j}=\left\{\begin{array}{cc}
\max \left\{\tau_{i, j}\left[\eta_{i, j}\right]^{\beta}\right\}, \quad \text { bila } q \leq q_{0} \\
\max \frac{\left\{\tau_{i, j}\left[\eta_{i, j}\right]^{\beta}\right\}}{\sum_{m=0}^{m_{i}}\left\{\tau_{i, m}\left[\eta_{i, m}\right]^{\beta}\right\}}, \quad \text { bila } q \geq q_{0} \\
\eta_{i, j}=\frac{1}{F_{i j}}
\end{array}\right.
$$

$\tau_{i j}$ adalah pheromone pada $\operatorname{arc}(i, j), \eta_{i j}$ adalah invers dari pada $\operatorname{arc}(i, j), U_{k}$ merupakan himpunan simpul yang belum dikunjungi semut ke-k yang berada pada simpul i [6].

\section{8) Local Pheromone Update}

Setiap kali membentuk tour, semut-semut tersebut akan melewati arc yang ada dan mengubah besarnya pheromone [11]. Hal ini ditunjukan pada persamaan (10).

$$
\tau_{i j} \leftarrow(1-\rho) \tau_{i j}+\rho \Delta \tau_{i j}, 0<\rho<1
$$

\section{9) Global Pheromone Update}

Setelah semua semut telah melalui setiap simpul maka besarnya jumlah pheromone akan berubah berdasarkan persamaan global updating rule yang ditunjukan pada persamaan (11).

$$
\Delta \tau_{i j}=\frac{1}{\operatorname{Lgb}} \operatorname{untuk}(i, j) \in \text { global }- \text { best }- \text { tour }
$$

Dimana $L g b$ adalah panjang dari tour terbaik (terbaik) yang dihasilkan oleh sekumpulan semut tersebut.

\section{PEMODELAN SISTEM}

\section{A.Penerapan Algoritma ACO}

Algoritma Ant Colony Optimizatiin merupakan metode yang akan digunakan dalam menyelesaikan perhitungan biaya ekonomis pada permasalahan DED. Bentuk alur ACO dapat dilihat pada flowchart Gambar 4.

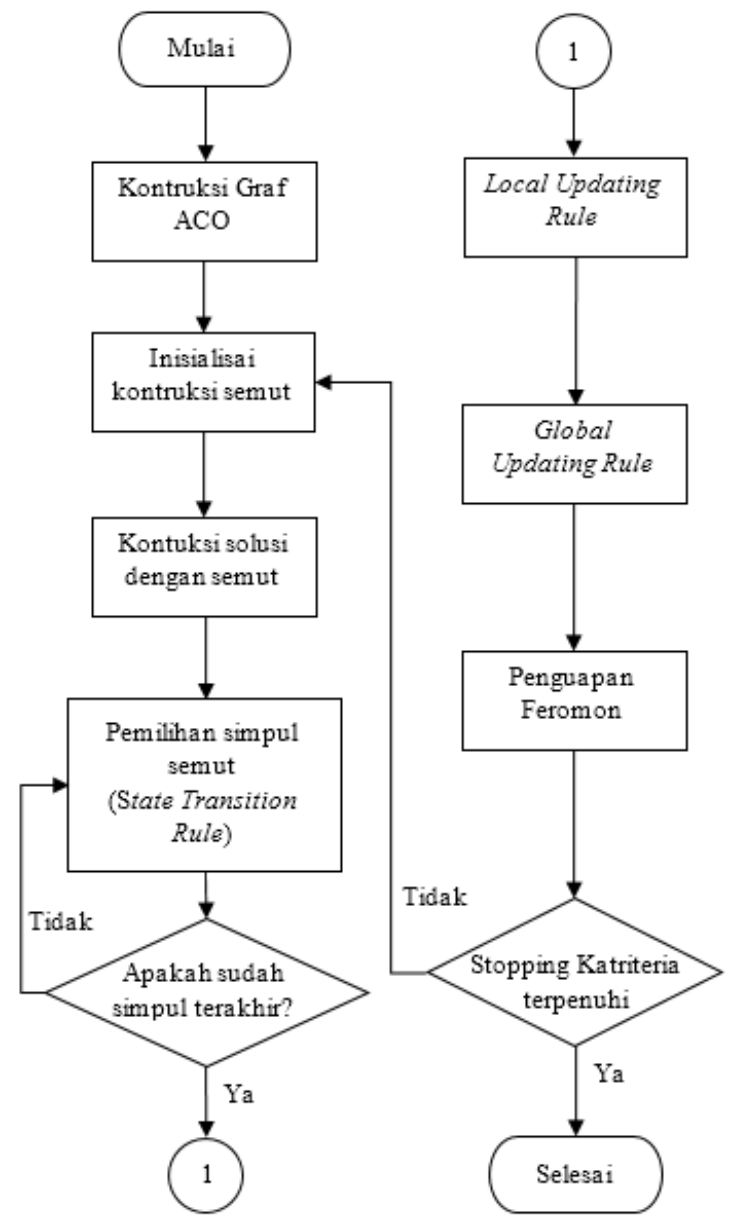

Gambar 4. Flowchart Algoritma ACO

\section{B. Inisialisai Permasalahan DED}

Permasalahan DED merupakan permasalahan ED yang berulang dengan rentang waktu 24 jam. Sehingga variabel waktu perlu ditambahkan pada tiap permasalahan ED [5]. Konstrain kesetimbangan daya tanpa mempertimbangkan kerugian daya ditunjukkan pada persamaan (12).

$\sum_{t=1}^{T} \sum_{i=1}^{N} P_{i}^{t}=\sum_{t=1}^{T} P_{D}^{t}$

Variabel waktu dari DED berakibat pada penentuan batas maksimum dan minimum generator tiap waktu akan bervariasi 
bergantung output daya pada waktu sebelumnya dan batasan maksimum dan minimum desain. Sesuai dengan karakteristik batasan ramp rate pada pembangkit [6]. Sehingga penentuan batas atas dan batas bawah dari daya yang dibangkitkan oleh generator untuk tiap jam berikutnya dapat dituliskan pada persamaan (13).

$$
\begin{gathered}
P_{\min , i}^{t}=\max \left(P_{\min , i}, P_{i}^{t-1}-D R_{i}\right) \\
P_{\max , i}^{t}=\min \left(P_{\max , i}, P_{i}^{t-1}+U R_{i}\right)
\end{gathered}
$$

\section{Perancangan Plant}

Pada studi ini menggunakan dua plant yang akan digunakan untuk pengujian perhitungan dynamic economic dispatch. Data pengujian pertama yang digunakan yaitu berdasarkan jurnal IEEE sistem tenaga listrik 5 Unit pembangkit dengan pertimbangan valve point effect menggunakan metode Ant Colony Optimization [8]. Data pengujian kedua yang digunakan yaitu berdasarkan jurnal IEEE sistem tenaga listrik 10 Unit pembangkit dengan pertimbangna valve point effect dan multiple fuel options [9]

Pada plant ke-2 ketika MFO masuk dalam pertimbangan, diasumsikan setiap 1 area unit pembangkit terdapat 3 jenis generator dengan biaya bahan bakar yang berbeda [9]. Utntuk batas atas dan datas bawah oprasi generator serta fungsi biaya yang digunakan dari tiap generator direpresentasikan dalam persamaan (14) dan (15).

$$
\begin{aligned}
& P_{1, i}^{L_{M O F}}=P_{i}^{\text {min }} ; P_{1, i}^{U_{M F O}}=P_{i}^{\text {min }}+0.333\left(P_{i}^{\text {max }}-P_{i}^{\text {min }}\right) \\
& P_{2, i}^{L_{M O F}}=P_{1, i}^{U_{M F O}} ; P_{2, i}^{U_{M F O}} \\
&=P_{i}^{\text {min }}+0.667\left(P_{i}^{\text {max }}-P_{i}^{\text {min }}\right) \\
& P_{3, i}^{L_{M O F}}=P_{2, i}^{U_{M F O}} ; P_{3, i}^{U_{M F O}}=P_{i}^{\text {min }}
\end{aligned}
$$

$$
\begin{gathered}
a_{1 . i}=a_{i} \quad ; \quad b_{1 . i}=b_{i} \quad ; \quad c_{1 . i}=c_{i} \\
a_{2 . i}=1.1 a_{i} ; \quad b_{2 . i}=1.1 b_{i} ; \quad c_{2 . i}=1.1 c_{i} \\
a_{3 . i}=1.2 a_{i} ; \quad b_{3 . i}=1.2 b_{i} ; \quad c_{3 . i}=1.2 c_{i}
\end{gathered}
$$

\section{Algoritma ACO Untuk Permasalahan DED}

ACO akan menentukan kombinasi daya output dari tiap unit pembangkit dengan biaya yang paling ekonomis untuk memenuhi permintaan beban dalam periode waktu. Parameter yang digunakan pada algoritma ACO untuk menyelesaikan permasalahan DED ditunjukkan pada Tabel 1.

Tabel 1.

Tabel Korelasi Parameter ACO

\begin{tabular}{cl}
\hline \hline Parameter & \multicolumn{1}{c}{ Keterangan } \\
\hline Graf ACO & $\begin{array}{l}\text { Berupa vektor dari kenaikan level daya pembangkit } \\
\text { dari } \mathrm{P}_{\min }-\mathrm{P}_{\max } \text { berdasarkan interval yang ditentukan. }\end{array}$ \\
$\begin{array}{c}\text { Feromone }(\tau) \\
\text { Berupa nilai daya yang berada pada jalur Graf. }\end{array}$ \\
$\begin{array}{cl}\text { Individu semut } \\
(\mathrm{m})\end{array}$ & $\begin{array}{l}\text { Variable yang menginisialisasikan fungsi biaya } \\
\text { dengan batasan inequality dan equality constrain. }\end{array}$ \\
$(\beta)$ & $\begin{array}{l}\text { Sebuah hubungan parameter mengenai jarak (biaya) } \\
\text { dan feromon (daya). }\end{array}$ \\
$(\rho)$ & Intensitas penguapan pada feromon \\
\hline \hline
\end{tabular}

Pada tahap penjabaran graf ACO yang digunakan sebagai batas bawah adalah $\mathrm{P}_{\min }$ dan sebagai batas atas adalah $\mathrm{P}_{\max }$ dari masing-masing pembangkit dibuat interval titik sebanyak $n$ level daya dari batas bawah sampai batas atas generator sesuai pada persamaan (17)

$$
P_{i}^{j}=P_{i}^{\min }+(j-1)\left(\frac{P_{i}^{\max }-P_{i}^{\text {min }}}{N-1}\right)
$$

Pada pembangkit yang terakhir dilakukan perhitungan reduksi variable dengan cara beban yang diminta dikurangi dengan penjumlahan daya dari pembangkit 1 sampai pembangkit $\mathrm{g}-1$ sesuai pada persamaan (18).

$$
P_{g}=P_{D}-\sum_{i=1}^{g-1} P_{i}
$$

Penentuan solusi terbaik yang memungkinkan harus mematuhi konstarain keseibangan daya dan batasan oprasi. Aturan mini maxi digunakan untuk mengatasi permasalahn tersebut. Maka persamaan (20) dan (21) perlu disertakan pada state transition rule.

$$
\begin{gathered}
\text { maxi } \leq \text { beban }-\sum_{\substack{i=1 \\
k=g}}^{k=g} P_{k}-\sum_{\substack{i=1 \\
k=g}}^{k=g} P_{g-k}^{\max } \\
\text { mini } \geq \text { beban }-\sum_{i=1}^{k} P_{k}-\sum_{i=1}^{\min } P_{g-k}^{\min }
\end{gathered}
$$

\section{SIMULASI DAN ANALISIS}

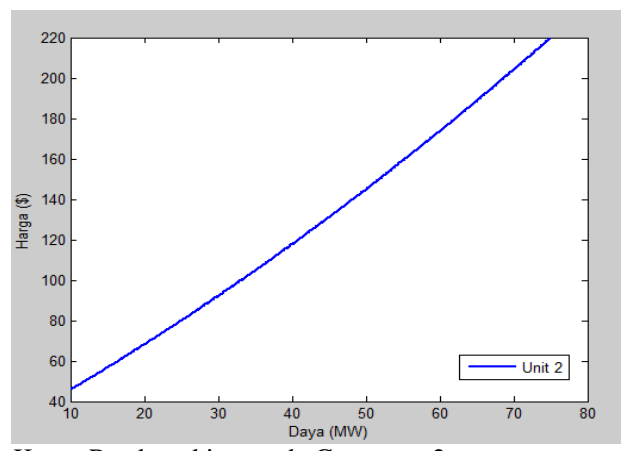

Gambar 5. Kurva Pembangkitan pada Generator 2

\section{A. Analisis DED 5 Unit Pembangkit Tanpa VPE}

Parameter ACO yang digunakan yaitu:

1. Populasi semut $(\mathrm{m})$ sebesar 30

2. Tingkat penguapan feromon $(\rho) 0.9$

3. Tingkat relatif informasi heuristik $(\beta)$ sebesar 0.7

4. Jumlah simpul dalam penjabaran graf (n) sebesar 200

5. Intensitas feromon mula-mula $(\tau)$ sebesar 0.8

Simulasi kasus I akan dilakukan sesuai dengan permintaaan beban selama 24 jam dengan total beban 14,577 MW. Hasil simulasi DED tanpa melibatkan VPE sehingga kurva pembangkitan tiap generator berbentuk non-linier dengan orde dua seperti pada Gambar 5 yaitu kurva pembangkitan pada generator 2. Biaya total pembangkitan \$39,732.10 dan 14,578.6 MW. Hal ini menunjukkan bahwa hasil simulasi sudah memenuhi batasan yang digunakan, seperti equality constrain $\left(\mathrm{P}_{\mathrm{d}}=\mathrm{P}_{\mathrm{g}}\right)$, inequality constrain $\left(\mathrm{P}_{\min }\right.$ dan $\left.\mathrm{P}_{\max }\right)$ serta ramp-rate generator.

\section{B. Analisis DED 5 Unit Pembangkit Tanpa VPE}

Dengan parameter yang sama dan permintaan beban yang sama didapatkan biaya total pembangkitan dengan pertimbangan VPE yaitu sebesar $\$ 42,792.40$ dan daya yang dibangkitkan 14,579.5 MW.

Effek dari valve point memberikan perubahan biaya dan jauh lebih mahal yakni \$3,060.50 atau 7.7\% dari total tanpa VPE. Maka dari itu VPE dalam perhitungan DED penting 
untuk tidak diabaikan. Tabel 2 menunjukkan hasil perbandingan antara kasus I dengan kasus II dengan plant yang sama. Gambar 6 yaitu kurva pembangkitan pada generator 5 .

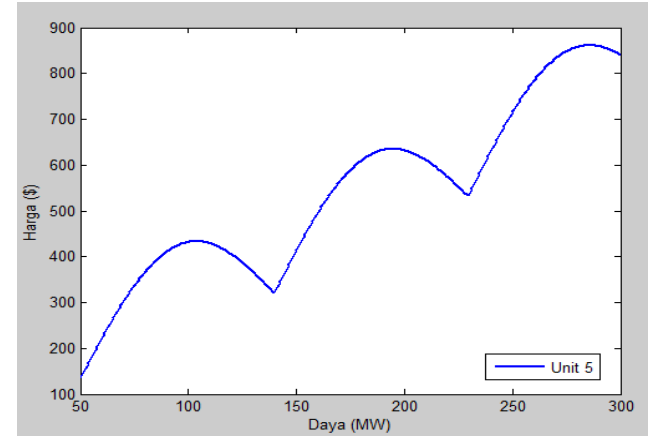

Gambar 6. Kurva Pembangkitan pada Generator 5 dengan 3 Katup Pembukaan

Tabel 2.

Tabel Perbandingan Pada Plant I

\begin{tabular}{lrr}
\hline \hline $\begin{array}{l}\text { 5 Unit } \\
\text { Pembangkit }\end{array}$ & \multicolumn{1}{c}{ Harga } & Waktu Komputasi (s) \\
\hline Kasus I & $\$ 39,731.90$ & 344.87 \\
Kasus II & $\$ 42,972.40$ & 470.13 \\
\hline \hline
\end{tabular}

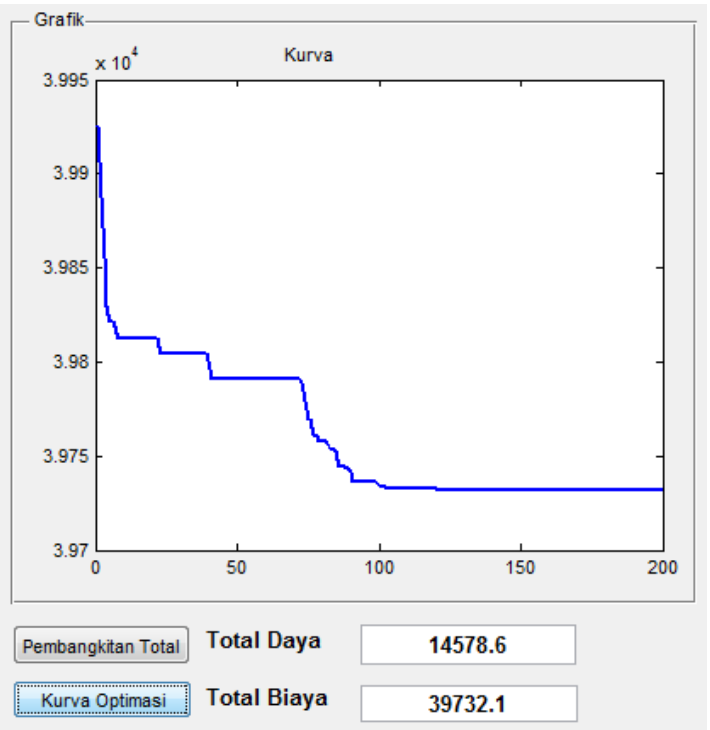

Gambar 7. Kurva Konvergensi IEEE 5 Unit Generator

Algoritma ACO yang digunakan untuk permasalahan DED 5 Unit pembangkit memberikan hasil konvergensi dengan lama komputasi yaitu 344.87 detik yang ditunjukkan pada Gambar 7 dengan total daya yang optimal dan biaya pembangkitan yang ekonomis.

C. Analisis DED 10 Unit Pembangkit Mempertimbangkan VPE

Simulasi kasus III akan dilakukan sesuai dengan permintaaan beban selama 24 jam dengan total beban 42,100 MW. Hasil simulasi DED hanya melibatkan VPE biaya total pembangkitan $\$ 1,012,058.00$. Daya yang dibangkitkan dalam satu periode yakni 40,098.9 MW. Hal ini menunjukkan bahwa hasil simulasi sudah memenuhi batasan yang digunakan, seperti equality constrain $(\mathrm{Pd}=\mathrm{Pg})$, inequality constrain (Pmin dan Pmax) serta ramp-rate generator. Hasil simulasi DED dengan melibatkan VPE sehingga kurva pembangkitan tiap generator menja non-linear orde tinggi seperti pada Gambar 8 yaitu kurva pembangkitan pada Generator 2. Sistem tenaga listrik dengan 10 Unit pembangkit ini masing-masing terdiri dari 3 tipe bahan bakar yang berbeda, shingga memberikan 3 jenis fungsi biaya yang berbeda pula [9].

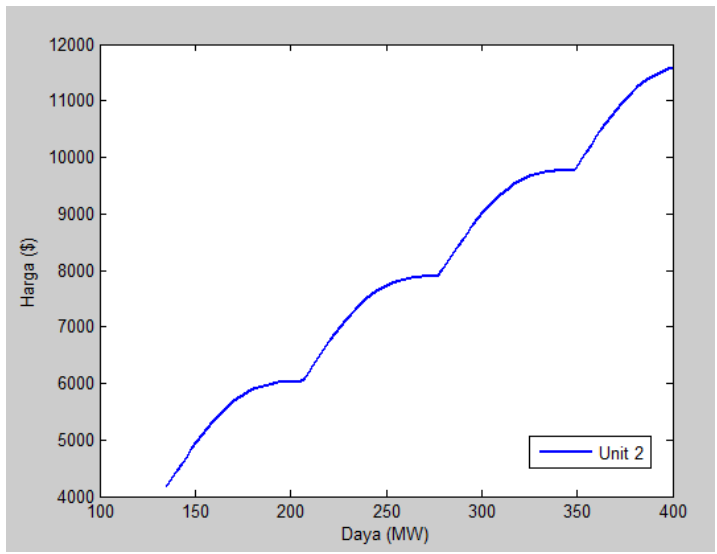

Gambar 8. Kurva pembangkitan pada Generator 2 dengan 4 Katup

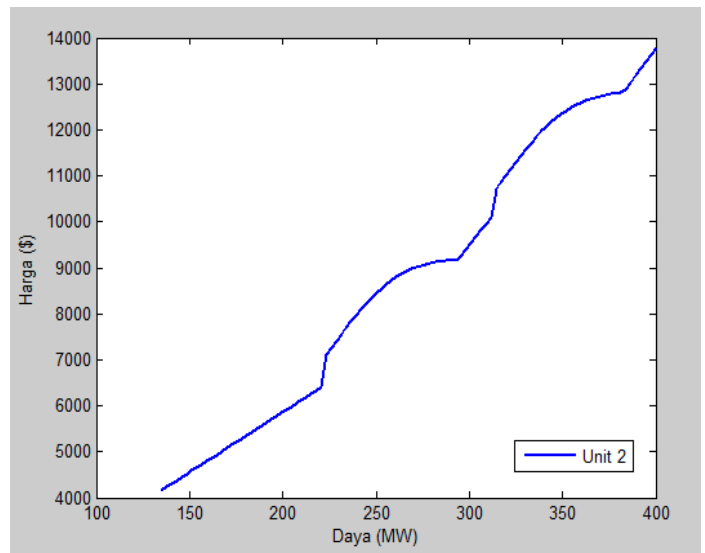

Gambar 9. Kurva Pembangkitan pada Generator 2 dengan pertimbangan VPE dan MFO

\section{Analisis DED 10 Unit Pembangkit Mempertimbangkan VPE dan MFO}

Menggunakan parameter yang sama dan permintaan beban yang sama didapatkan biaya total pembangkitan dengan pertimbangan VPE dan MFO yaitu sebesar \$ 1,026,587.00 daya yang dibangkitkan yakni 40.101,5 MW. Artinya total daya yang terbangkit memenuhi permintaan beban. Sedangkan batasan oprasi dengan mempertimbangkan ramp rate seperti terlihat Tabel 3 pada Unit 2 jam ke-15 daya yang dibangkitkan sebesar 434.9 MW. Pada jam ke-16 daya yang dibangkitkan sebesar 365.7 MW. Maka selisih daya terbangkitkan adalah $69.2 \mathrm{MW}$ dan batasan ramp rate untuk unit 2 adalah 80 artinya daya yang dibangkitkan setiap jam oleh masing-masing pembangkit masih dalam batasan ramp rate.

Effek dari MFO memberikan perubahan biaya dan jauh lebih mahal yakni \$14,529.00 atau $1.43 \%$ dari total biaya termahal. Maka dari itu MFO dalam perhitungan DED penting untuk tidak diabaikan. Tabel 4 menunjukkan hasil perbandingan antara kasus III dengan kasus IV dengan plant yang sama. Gambar 9 yaitu kurva pembangkitan pada generator 2 . 
Tabel 4.

Perbandingan Pada Plant II

\begin{tabular}{lcr}
\hline \hline $\begin{array}{c}\text { 10 Unit } \\
\text { Pembangkit }\end{array}$ & Harga & $\begin{array}{c}\text { Waktu Komputasi } \\
\text { (s) }\end{array}$ \\
\hline Kasus III & $\$ 1,012,058.00$ & 2554.83 \\
Kasus IV & $\$ 1,130,025.00$ & 2612.82 \\
\hline \hline
\end{tabular}

Pengaruh dari penambahan parameter yaitu VPE dan MFO menyebabkan kurva biaya pembangkitan yang tidak mulus. Hal ini dapat dilihat pada Gambar 10 yaitu perbandingantanpa penambahan dan penambahan parameter VPE dan MFO pada Unit 2 untuk Plant II sistem dengan 10 Unit Generator. Sehingga menyebabkan biaya pembangkitan lebih mahal dengan adanya parameter VPE dan MFO. Penambahan parameter yang dilakukan bertujuan untuk mendapatkan perhitungan optimasi dengan ketepatan yang sebaik mungkin berdasarkan dengan kondisi pembangkit yang sebenarnya.

Metode ACO mampu bekerja secara optimal untuk sistem IEEE 5 Unit Generator seperti yang terlihat pada Tabel 5 sebagai komparasi dengan metode pembanding lainnya yaitu Mixed Integer Quadratic Program (MIQP) serta metode lainnya. Hasil yang didapatkan dengan menggunakan metode ACO biaya pembangkitan sudah mendapatkan hasil yang optimal untuk sistem IEEE 10 Unit Pembangkit yakni jauh lebih murah namun waktu komputasinya relative lebih lama.

Tabel 5 .

Komparasi Metode Untuk 10 Unit Pembangkit

\begin{tabular}{|c|c|c|}
\hline Metode & Toral Biaya (\$) & $\begin{array}{l}\text { Waktu Komputasi } \\
\text { (menit) }\end{array}$ \\
\hline SQP & $\$ 1,051,163.00$ & 1.19 \\
\hline $\mathrm{EP}$ & $\$ 1,048,638.00$ & 42.29 \\
\hline Hybrif & $\$ 1,035,748.00$ & 20.51 \\
\hline MIQP & $\$ 1,027,768.00$ & 4.5 \\
\hline $\mathrm{ACO}$ & $\$ 1,026,587.00$ & 43.53 \\
\hline
\end{tabular}

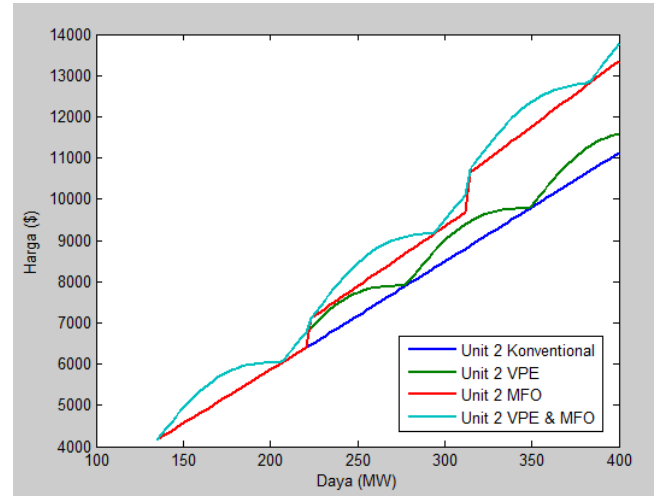

Gambar 10. Konvergensi IEEE 10 Unit Generator dengan VPE dan MFO

\section{KESIMPULAN}

Berdasarkan hasil yang didapatkan dari simulasi dan analisis pada studi ini, dapat diambil beberapa kesimpulan sebagai berikut:

1. Penentuan parameter ACO berdasarkan banyaknya jumlah pembangkit serta besarnya daya maksimum dan minimum yang dibangkitkan oleh masing-masing generator. Kombinasi dari parameter ACO yang tepat mempengaruhi efektifitas dalam hal lain sperti waktu komputasi serta optimasi dari fungsi objektif yang dihasilkan (konvergen).

2. Semakin besar selisih daya yang dibangkitkan generator $\left(\mathrm{P}_{\min }-\mathrm{P}_{\max }\right)$ maka simpul yang dibangun juga harus lebih besar seperti pada plant I dan plant II untuk hasil yang optimal.

3. Fungsi biaya dengan penambahan VPE memberikan selisih $8.25 \%$ atau sebesar \$ 3,577.6 dari total harga perhitungan DED tanpa mempertimbangkan VPE. Maka kendala ini penting untuk tidak diabaikan dalam perhitungan optimasi DED.

4. Pengaruh dari MFO pada kasus III dan kasus IV. Peningkatan biaya yang dihasilakan sebesar $8.28 \%$ dengan selisih biaya dengan mempertimbangkan MFO sebesar \$93,665.00. Sehingga pertimbangan MFO merupakan kendala yang tidak dapat diabaikan dalam perhitungan optimasi DED.

Tabel 2.

Hasil Simulasi DED (24 jam) Kasus IV Plant 2 Bagian1

\begin{tabular}{|c|c|c|c|c|c|c|c|c|c|c|c|c|}
\hline \multirow[b]{2}{*}{ Jam } & \multicolumn{10}{|c|}{ Unit } & \multirow{2}{*}{ Harga } & \multirow{2}{*}{ Daya } \\
\hline & P1 & $\mathbf{P 2}$ & P3 & P4 & P5 & P6 & P7 & P8 & P9 & P10 & & \\
\hline 1 & 155.6 & 234.0 & 143.3 & 60.0 & 77.4 & 114.3 & 129.4 & 47.0 & 20.0 & 55.0 & $\$ 28,482.00$ & 1036.0 \\
\hline 2 & 161.0 & 230.0 & 213.7 & 60.9 & 73.5 & 118.5 & 130.0 & 47.0 & 20.4 & 55.0 & $\$ 30,047.00$ & 1110.0 \\
\hline 3 & 182.5 & 296.2 & 282.1 & 62.7 & 73.1 & 110.0 & 130.0 & 47.1 & 20.3 & 55.0 & $\$ 33,420.00$ & 1258.9 \\
\hline 4 & 190.1 & 273.3 & 303.5 & 98.7 & 114.7 & 159.4 & 130.0 & 56.4 & 25.0 & 55.0 & $\$ 36,570.00$ & 1406.0 \\
\hline 5 & 258.3 & 337.6 & 318.8 & 76.9 & 127.4 & 110.0 & 130.0 & 47.0 & 20.0 & 55.0 & $\$ 38,450.00$ & 1481.0 \\
\hline 6 & 194.7 & 337.1 & 320.0 & 126.9 & 177.4 & 160.0 & 130.0 & 77.0 & 50.0 & 55.0 & $\$ 41,867.00$ & 1628.0 \\
\hline 7 & 269.9 & 413.6 & 305.9 & 93.3 & 145.2 & 159.5 & 130.0 & 69.6 & 60.0 & 55.0 & $\$ 43,611.00$ & 1702.0 \\
\hline 8 & 202.1 & 410.8 & 320.0 & 143.3 & 195.2 & 160.0 & 130.0 & 99.6 & 60.0 & 55.0 & $\$ 45,342.00$ & 1776.1 \\
\hline 9 & 184.7 & 458.2 & 320.0 & 193.3 & 243.0 & 160.0 & 130.0 & 120.0 & 60.0 & 55.0 & $\$ 48,878.00$ & 1924.2 \\
\hline 10 & 264.7 & 460.0 & 320.0 & 243.3 & 243.0 & 160.0 & 130.0 & 120.0 & 60.0 & 55.0 & $\$ 51,791.00$ & 2056.0 \\
\hline 11 & 306.8 & 457.9 & 320.0 & 293.3 & 243.0 & 160.0 & 130.0 & 119.9 & 60.0 & 55.0 & $\$ 53,883.00$ & 2146.0 \\
\hline 12 & 380.8 & 452.9 & 318.7 & 299.7 & 243.0 & 160.0 & 130.0 & 120.0 & 60.0 & 55.0 & $\$ 55,511.00$ & 2220.1 \\
\hline
\end{tabular}




\begin{tabular}{rrrrrrrrrrrrr}
\hline \hline 13 & 411.2 & 456.7 & 275.4 & 265.0 & 209.8 & 129.8 & 130.0 & 102.9 & 37.0 & 55.0 & $\$ 51,773.00$ & 2072.8 \\
14 & 413.8 & 433.1 & 279.8 & 242.8 & 160.2 & 110.0 & 130.0 & 79.9 & 20.0 & 55.0 & $\$ 48,297.00$ & 1924.5 \\
15 & 429.9 & 434.9 & 214.7 & 193.2 & 138.6 & 110.0 & 130.0 & 49.9 & 20.2 & 55.0 & $\$ 44,949.00$ & 1776.4 \\
16 & 436.0 & 365.7 & 154.0 & 143.8 & 88.6 & 110.0 & 130.0 & 50.8 & 21.2 & 55.0 & $\$ 39,878.00$ & 1554.9 \\
17 & 373.5 & 405.9 & 151.2 & 94.8 & 91.3 & 110.0 & 130.0 & 47.3 & 21.6 & 55.0 & $\$ 38,368.00$ & 1480.6 \\
18 & 416.9 & 434.5 & 122.8 & 64.2 & 129.8 & 160.0 & 130.0 & 63.2 & 51.6 & 55.0 & $\$ 41,925.00$ & 1628.0 \\
19 & 434.6 & 373.3 & 176.0 & 114.2 & 179.8 & 160.0 & 130.0 & 93.2 & 59.9 & 55.0 & $\$ 45,402.00$ & 1776.0 \\
20 & 453.9 & 450.4 & 252.1 & 161.6 & 229.2 & 160.0 & 130.0 & 120.0 & 60.0 & 55.0 & $\$ 52,353.00$ & 2072.3 \\
21 & 446.9 & 446.4 & 295.1 & 138.9 & 181.5 & 110.0 & 130.0 & 91.2 & 30.0 & 55.0 & $\$ 48,155.00$ & 1924.9 \\
22 & 391.9 & 423.0 & 217.4 & 88.9 & 131.5 & 110.0 & 130.0 & 61.2 & 20.0 & 55.0 & $\$ 41,269.00$ & 1628.9 \\
23 & 314.3 & 364.6 & 150.6 & 60.0 & 81.5 & 110.0 & 130.0 & 47.0 & 20.0 & 55.0 & $\$ 34,681.00$ & 1332.9 \\
24 & 275.0 & 323.1 & 73.0 & 73.4 & 77.6 & 110.9 & 130.0 & 47.0 & 20.0 & 55.0 & $\$ 31,685.00$ & 1185.0 \\
& & & & & & & & & & & $\$ 1,026,587.00$ & 40101.5 \\
\hline \hline
\end{tabular}

\section{DAFTAR PUSTAKA}

[1] L. M. Ali, "Modification of multi-area economic dispatch with multiple fuel options, considering the fuelling limitations," IET Gener. Transm. Distrib, vol. 8, pp. 1098-1106, 2013.

[2] L. Dika, "Dynamic Economic Dispatch dengan Mempertimbangkan Kerugian Transmisi Menggunakan Metode Squential Quadratic Program," ITS Surabaya, vol. 16, no. 1, pp. 1$5,2015$.

[3] D. R. K. S. S. Vijayaraj, "Multi-Area Economic Dispatch with Multi Fuel Option Using Improved Bat Algorithm," IJIRS, Eng. Technol., vol. 5, 2016.

[4] D. R. K. S. S. Vijayaraj, "Application of EP to Multiple Fue Options Economic Dispatch," IJIRS, Eng. Technol., vol. 3, 2014.
[5] H. Saadat, Power system analysis. Boston: WCB/McGraw-Hill, 1999.

[6] M. Atya, "Implementasi Algoritma Ant Colony Optimization Untuk Menyelesaikan Permasalahan Dynamic Economic Dispatch Dengan Memperhatikan Rugi Rugi Daya Transmisi dan Valve Point Effect," ITS Surabaya, vol. 1, pp. 1-6, 2012.

[7] I. N. Saravuth. Pothiya, "Ant colony optimisation for economic dispatch problem with non-smooth cost functions," Electr. Power Energy Syst., vol. 17, pp. 478-487, 2010.

[8] I. N. Saravuth. Pothiya, "Dynamic Economic Dispatch with ValvePoint Effect Using Maclaurin Series Based Lagrangian Method," Apl. Int. J. Comput., vol. 1, no. 17, pp. 1-8, 2010.

[9] M. Y. and M. X. W. M. Q. Wang, X. S. Han, "Dynamic Economic Dispatch with Valve Point Effect, Prohibited Operation Zones, and Multiple Fuel Option," in IEEE PES Asia-Pacific Power and Energy Engineering Conference (APPEEC), 2014, pp. 1-5. 